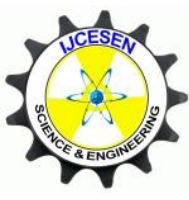

Copyright (C) IJCESEN
International Journal of Computational and

Experimental Science and $\boldsymbol{E N g i n e e r i n g}$

(IJCESEN)

Vol. 5-No.1 (2019) pp. 19-22

http://dergipark.gov.tr/ijcesen

Research Article

\title{
Utilization of Marble and Boron Waste in Brick Products
}

\author{
Atilla EVCIN ${ }^{1 *}$, Bahri ERSOY ${ }^{2}$, Hakan ÇIFTÇí2 \\ ${ }^{1}$ Afyon Kocatepe University, Department of Material Science and Engineering, , 03200, Afyonkarahisar, Turkey \\ ${ }^{2}$ Afyon Kocatepe University, Department of Mining Engineering, 03200, Afyonkarahisar, Turkey \\ * Corresponding Author : evcin@aku.edu.tr \\ ORCID: 0000-0002-0163-5097
}

\section{Article Info:}

DOI: $10.22399 /$ ijcesen. 480487

Received : 08 November 2018

Accepted : 27 December 2018

\section{Keywords}

Marble waste

Boron waste

Brick

Characterization

\begin{abstract}
$\underline{\text { Abstract: }}$
In this study, usability of marble and boron wastes as alternative raw materials in the production of bricks was investigated. They were used in different ratios to prepare samples. Marble waste in concentrations of 5, 10, 15 and $20 \mathrm{wt} \%$ were added to the boron waste. Afyon brick clay was used as a binder in $10 \mathrm{wt} \%$. Specimens were shaped by hydraulic press and fired at temperatures from 850 to $1050{ }^{\circ} \mathrm{C}$ for 4 hours. The crystalline structure and morphologies of the samples are characterized by X-ray powder diffractometer (XRD) and scanning electron microscopy (SEM), respectively. Flexural strengths of samples were measured. Acceptable mechanical properties have been obtained from the brick sample containing $5 \mathrm{wt} \%$ marble waste, $85 \mathrm{wt} \%$ boron waste and $10 \mathrm{wt} \%$ clay sintered at $1050{ }^{\circ} \mathrm{C}$ for 4 hours.
\end{abstract}

\section{Introduction}

Marble and boron wastes are one of the major environmental problems in Turkey. Only in Afyon province, disposed waste marble material is about 12 million tones/year and amount of boron waste resulting from the boron plants in Turkey is more than one million tone in a year[1-2]. There is an urgent demand to manage it in order to reduce the environmental impact. Large areas have to be allocated for disposal of them. Thus, waste storage causes environmental pollution and economical loss [3-5]. There are many studies on the use of marble and boron wastes as additive or filling materials in various applications such as ceramic [6-8], concrete [9-10], brick [11], and building materials [12].

In this study boron and marble wastes were evaluated in brick product. They were mixed in different proportions and shaped by hydraulic press. Then they were characterized by mechanic test, Xray diffraction (XRD), scanning electron microscopy (SEM).
Marble waste was supplied from Reis Marble Factory in Afyon. Boron waste was kindly supplied from Eti Maden Emet Boric Acid Factory in Emet, Kütahya. Marble and boron wastes were dried in oven at $100{ }^{\circ} \mathrm{C}$, then ground in jet mill under the size of $250 \mu \mathrm{m}$. In order to prepare brick samples powdered marble waste, powdered boron waste and Afyon brick clay as a binder were mixed in the compositions as given in Table 1. They were shaped by hydraulic press under $100 \mathrm{bar}$ and fired at temperatures from 850 to $1050{ }^{\circ} \mathrm{C}$ for 4 hours. The crystalline structure and morphologies of the brick samples were characterized by X-ray powder diffractometer (XRD) and scanning electron microscopy (SEM).

Table 1. Materials ratios in brick mixtures

\begin{tabular}{|c|c|c|c|}
\hline Samples & $\begin{array}{c}\text { Boron } \\
\text { waste, wt \% }\end{array}$ & $\begin{array}{c}\text { Marble } \\
\text { waste, wt\% }\end{array}$ & $\begin{array}{c}\text { Clay, } \\
\text { wt \% }\end{array}$ \\
\hline BM1 & 90 & - & 10 \\
\hline BM2 & 85 & 5 & 10 \\
\hline BM3 & 80 & 10 & 10 \\
\hline BM4 & 75 & 15 & 10 \\
\hline BM5 & 70 & 20 & 10 \\
\hline
\end{tabular}

\section{Materials and Method}


Table 2. Chemical analysis of boron and marble wastes.

\begin{tabular}{|c|c|c|c|c|c|c|c|c|c|c|c|c|}
\hline \multirow{2}{*}{$\begin{array}{c}\text { Boron } \\
\text { waste }\end{array}$} & Component & $\mathrm{CaO}$ & $\mathrm{SiO}_{2}$ & $\mathrm{MgO}$ & $\mathrm{Al}_{2} \mathrm{O}_{3}$ & $\mathrm{Fe}_{2} \mathrm{O}_{3}$ & $\mathrm{~K}_{2} \mathrm{O}$ & $\mathrm{SO}_{3}$ & $\mathrm{Cr}_{2} \mathrm{O}_{3}$ & $\mathrm{SrO}$ & $\mathrm{B}_{2} \mathrm{O}_{3}$ & $\mathrm{LOI}$ \\
\cline { 2 - 14 } & $\mathrm{Wt}(\%)$ & 36.7 & 9.96 & 2.33 & 1.66 & 2.64 & 0.92 & 20.5 & 1.24 & 2.27 & 1.21 & 19.5 \\
\hline \multirow{2}{*}{$\begin{array}{c}\text { Marble } \\
\text { waste }\end{array}$} & $\mathrm{Component}$ & $\mathrm{CaO}$ & $\mathrm{SiO}_{2}$ & $\mathrm{MgO}$ & $\mathrm{Al}_{2} \mathrm{O}_{3}$ & $\mathrm{Fe}_{2} \mathrm{O}_{3}$ & $\mathrm{~K}_{2} \mathrm{O}$ & - & - & - & - & $\mathrm{LOI}$ \\
\cline { 2 - 13 } & $\mathrm{Wt}(\%)$ & 54.30 & 0.75 & 0.22 & 1.15 & 0.20 & 0.23 & - & - & - & - & 43.20 \\
\hline
\end{tabular}

\section{Results and Discussion}

The best sintered samples at each temperature and mechanical strengths of fired samples in each composition were given in Fig. 1 and Fig. 2, respectively. As clearly seen from Fig. 2, the flexural strength of brick decreases linearly with increase of marble waste addition. The maximum strength was obtained with BM1 sample. However, the bricks having BM2 composition gave the reasonable strength values. Considering the reusing of the marble waste in addition to the boron waste, the BM2 brick mixing was preferred as suitable composition. The figures also show that the best temperature for sintering is $1050{ }^{\circ} \mathrm{C}$ for the bricks. SEM images (Fig. 3) and XRD analysis (Fig.4) support this case. At $850{ }^{\circ} \mathrm{C}$, sintering is very poor and a heterogeneous structure with high porosity is seen. However, at $1050{ }^{\circ} \mathrm{C}$, some hydrated calcium sulphates in boron waste reacts with clay minerals and also $\mathrm{CaO}$ resulting from the thermal decomposition of marble waste in order to form akermanite mineral a kind of spinel phase. So that, the microstructure of the brick became more compact and homogeneous by means of solid-state sintering mechanism (Fig. 3).


Figure 1. The best fired samples at different temperatures.



Figure 2. Flexural strengths of samples fired at different temperatures. 

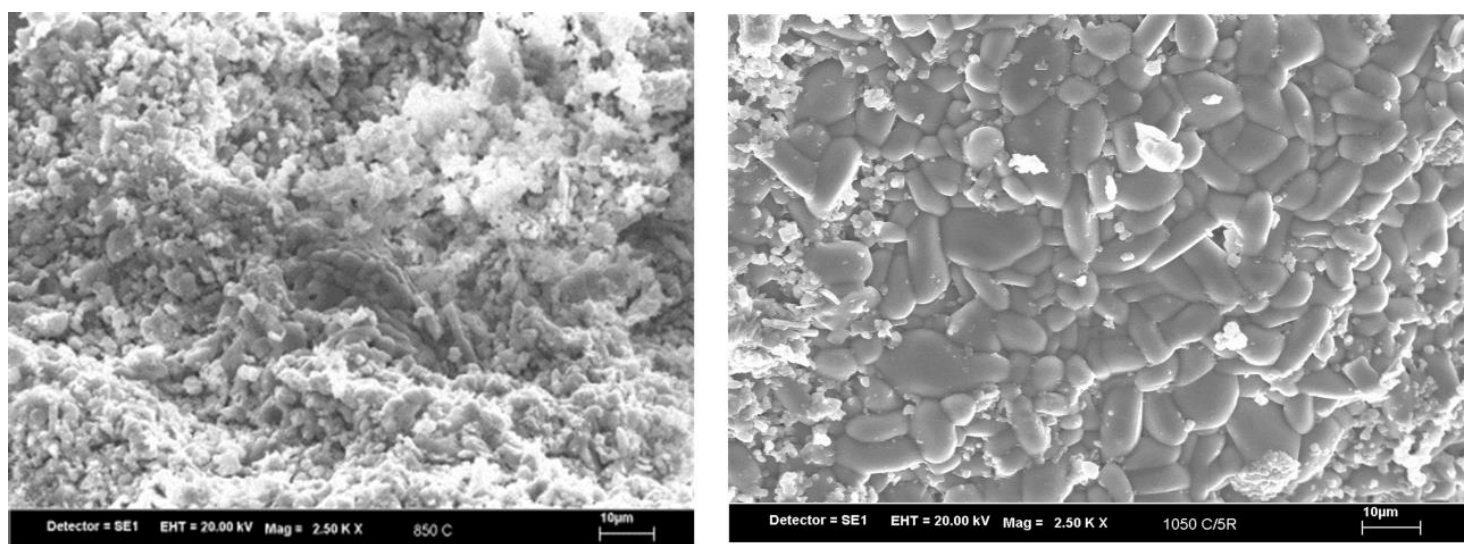

Figure 3. SEM images taken from the fracture surface of sintered BM2 samples at 850 (left) and $1050 \mathrm{oC}$ (right).

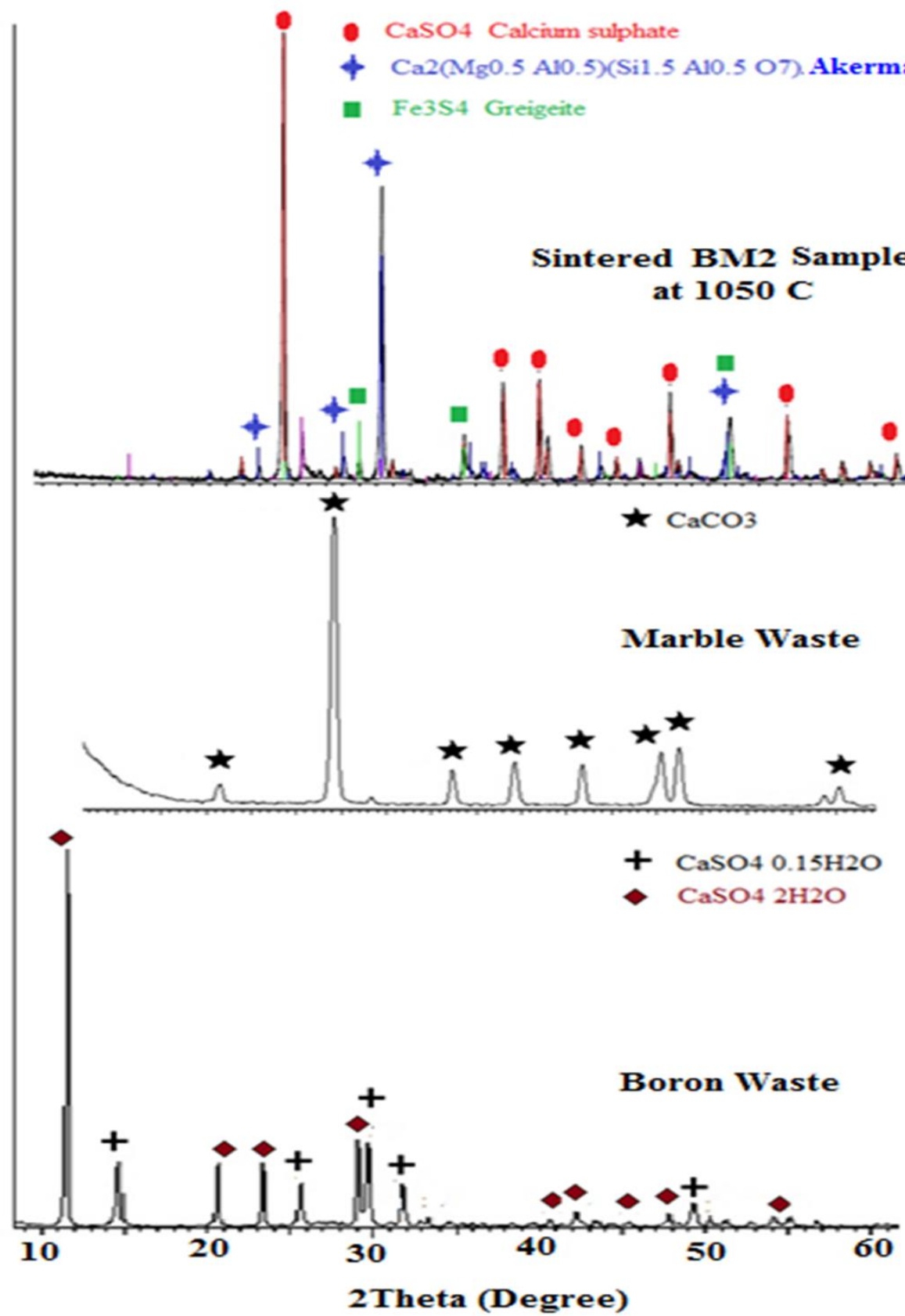

Figure 4. XRD pattern of raw materials and sintered BM2 sample. 


\section{Conclusion}

Considering utilization of both of the boron and marble wastes the best flexural strength ( 25 Mpa) value has been obtained from the brick sample containing $5 \mathrm{wt} \%$ marble waste, $85 \mathrm{wt} \%$ boron waste and $10 \mathrm{wt} \%$ clay sintered at $1050{ }^{\circ} \mathrm{C}$ for 4 hours. More than $5 \mathrm{wt} \%$ marble waste addition into brick composition decreases the flexural strength of the brick significantly.

\section{References}

[1] Ersoy, B., Sayın, Z. E., Arsoy, Z., Sayın Ü., Unaware of our underutilized resource:natural stone open pit and factory wastes, Mine/Pit Technologies, 27, (2015) 92- 100.

[2] L. Koroglu, E. Butev, Z. Esen, E. Ayas, A novel approach for synthesis of monticellite based bioactive ceramic powders from boron derivative wastes, Materials Letters, Volume 209, (2017) 315318. DOI: 10.1016/j.matlet.2017.08.034

[3] Ismail Sedat Buyuksagis, Tayfun Uygunoglu, Ertunc Tatar, Investigation on the usage of waste marble powder in cement-based adhesive mortar, Construction and Building Materials, Volume 154 (2017) 734-742 DOI: 10.1016/j.conbuildmat.2017.08.014

[4] H. Hebhoub, H. Aoun, M. Belachia, H. Houari, E. Ghorbel, Use of waste marble aggregates in concrete, Construction and Building Materials, Volume 25, Issue 3 (2011) 1167-1171. DOI: 10.1016/j.conbuildmat.2010.09.037.

[5] S. Özaveı and B. Çetin, Radiation Shielding Properties of Mortars and Plasters Used in Historical Buildings, Acta Physica Polonica A, Vol. 132
(2017)

986-987.

10.12693/APhysPolA.132.986

DOI:

[6] Selvin Yeşilay, Münevver Çakı, Hakan Ergun, Usage of marble wastes in traditional artistic stoneware clay body, Ceramics International, Volume 43, Issue 12 (2017) 8912-8921. DOI: 10.1016/j.ceramint.2017.04.028

[7] Bugra Cicek, Emirhan Karadagli, Fatma Duman, Valorisation of boron mining wastes in the production of wall and floor tiles, Construction and Building Materials, Volume 179 (2018) 232-244. DOI: 10.1016/j.conbuildmat.2018.05.182

[8] İ. Özkan, Utilization of Bigadiç Boron Works Waste Clay in Wall Tile Production, Acta Physica Polonica A, Vol. 132 (2017) 427-429 DOI: 10.12693/APhysPolA.132.427

[9] Hasan Şahan Arel, Recyclability of waste marble in concrete production, Journal of Cleaner Production, Volume $131 \quad$ (2016) 179-188. DOI: 10.1016/j.jclepro.2016.05.052.

[10] Tayfun Uygunoğlu, İlker Bekir Topçu, Atila Gürhan Çelik, Use of waste marble and recycled aggregates in self-compacting concrete for environmental sustainability, Journal of Cleaner Production, Volume 84 (2014) 691-700. DOI: 10.1016/j.jclepro.2014.06.019.

[11] Yüksel Abalı, Mehmet Ali Yurdusev, M. Sadrettin Zeybek, Ahmet Ali Kumanlıoğlu, Using phosphogypsume and boron concentrator wastes in light brick production, Construction and Building Materials, Volume 21, Issue 1 (2007) 52-56. DOI: 10.1016/j.conbuildmat.2005.07.009.

[12] Sarkar R, Das SK, Mandal PK, Maiti HS. Phase and microstructure evolution during hydrothermal solidification of clay-quartz mixture with natural stone dust source of reactive lime. J Eur Ceram Soc 26 (2006) 297-304. 